\title{
PEMBELAJARAN NEUROSAINS DALAM PEMBENTUKAN KARAKTER PESERTA DIDIK PADA PONDOK PESANTREN
}

\author{
Erniati \\ Institu Agama Islam Negeri (IAIN) Palu, Jln. Diponegoro No. 23 Palu \\ E-mail: Erniati_Labuaja@yahoo.com
}

\begin{abstract}
Learning neuroscience offers an alternative to the development of intelligence potential learners linguistic and logical through physical movement, rohamiah, physical, interpersonal, intrapersonal, naturalist and existential. The learning system includes morality codes of learners are packed in Islamic boarding school education curriculum with teaching presentation of cognitive, affective and psychomotor. Islamic education boarding school curriculum neurosains apply learning methods for the development of intellect learners so in the formation of character can maximize the performance of sense. In neuroscience of learning, students are given the opportunity to actively construct knowledge through learning. Thus, neuroscience learning combined with a variety of disciplines so integrated into the mainstream of the formation of character.
\end{abstract}

Abstrak. Pembelajaran neurosains menawarkan alternatif pengembangan potensi inteligensi peserta didik secara linguistik dan logis melalui gerak badani, rohaniah, jasmaniah, interpersonal, naturalis dan eksistensial. Sistem pembelajaran ini memuat sandi moralitas peserta didik yang dikemas dalam kurikulum pendidikan Islam pondok pesantren dengan penyajian pengajaran aspek kognitif, afektif dan psikomotorik. Pendidikan Islam pondok pesantren menerapkan metode pembelajaran kurikulum neurosains untuk pengembangan kecerdasan akal peserta didik dalam pembentukan karakter. Dalam pembelajaran neurosains, peserta didik diberi kesempatan untuk membangun pengetahuan secara aktif melalui proses belajar. Maka, pembelajaran neurosains dikombinasikan dengan berbagai disiplin ilmu sehingga terintegrasi dan menjadi arus utama pembentukan karakter.

Kata Kunci; Pembelajaran Neurosains, Karakter Peserta Didik 


\section{PENDAHULUAN}

Selama ini pendidikan Islam tidak menaruh perhatian serius pada neurosains padahal sangat penting dalam memaksimalkan kerja akal. ${ }^{1} L e b i h$ dari itu, neurosains menjadi alat pengembangan kurikulum pendidikan. Integrasi neurosains dalam pembelajaran telah menghasilkan berbagai teori belajar berbasis akal, seperti accelerated learning, brain based learning, quantum learning, quantum teaching dan contectual teaching and learning.

Perhatian pendidikan Islam terhadap neurosains berimplikasi pada pemahaman atas sistem kecerdasan (IQ, EQ dan $S Q)$ secara baik hingga saat ini. Pendidikan Islam menyatukan $I Q$, $E Q, S Q$. Penyatuan tersebut membentuk keseimbangan antara pengembangan kognitif, afektif dan psikomotorik. Namun, hal ini belum menjadi komitmen kolektif pemerintah dan lembaga pendidikan Islam untuk mewadai kecerdasan akal, jasmani, kognitif, afektif dan psikomotorik. ${ }^{2}$

Saat ini, penting untuk memasukkan mata pelajaran tentang akal (neurosains) kurikulum lembaga pendidikan Islam. Sehingga keberhasilan pembelajaran berbasis otak, seperti Brain Based learning, Quantum Learning, Quantum Teaching sebagai sumbangsih neurosains untuk dunia pendidikan. Dalam konteks pendidikan Islam terutama di pondok pesantren, kecerdasan merupakan hal pokok dalam pengembangan potensi peserta didik terlebih pada pembentukan karakter dan rasionalitas, seperti IQ, EQ, SQ, MaQ, dan Multiple Intellegence. ${ }^{3}$ Pendidikan Islam merupakan lembaga pembentukan karakter akhlak mulia secara

${ }^{1}$ Howard Gardner, The School of The Future. In John Brockman (ed), Ways of Knowing: The Reality Club 3 (Englewood Cliffs, N.J.: Prentice Hall, 2002), h. 199-218

${ }^{2}$ Suyadi, Integrasi Pendidikan Islam dan Neurosains dan Implikasinya Bagi Pendidikan Dasar (PGMI) (Yogyakarta: Jurnal Al-Bidāyah, Vol 4 No. 1, Juni 2011). h. 17

${ }^{3}$ Agus Nggermanto, Quantum Qoutient (Kecerdasan Quantum): Cara Praktis Melejitkan IQ, EQ, dan SQ Yang Harmonis (Bandung: Nuansa, 2005). h. 44 
konkrit. Itupun di lakukan oleh pendidikan Islam pesantren sejak dini demi terciptanya pertumbuhan peserta didik yang sehat secara fisik, mental, sosial, emosional dan spiritual dengan baik.

Sesuai dengan Undang-undang No. 20 tahun 2003 pendekatan pendidikan Islam dalam pembentukan karakter sangat penting sekali untuk di didik secara tepat supaya menjadi manusia yang berkualitas sehingga potensi yang dimiliki para santri dalam berbagai kegiatan belajar dapat tercapai dalam kondisi lingkungan yang enak, nyaman dan senang. Selain itu, kurikulum neurosains juga penanaman nilai yang membentuk budi pekerti, nilai seni, nilai budaya, kecerdasan, keterampilan dan agama. ${ }^{4}$

\section{PARADIGMA KURIKULUM NEUROSAINS DAN OUTPUT HASIL BELAJAR}

Benjamin S. Bloom menyebutkan ada tiga ranah hasil belajar, yaitu kognitif, afektif dan psikomotorik. Hal ini merupakan hasil belajar dari pencapaian bentuk perubahan perilaku kearah kognitif, afektif dan psikomotorik dilakukan dalam waktu tertentu. Bloom membagi dan menyusun secara hirarkhis menjadi enam tingkat pengetahuan (C1), pemahaman (C2), aplikasi (C3), analisis (C4), sintesis (C5) dan evaluasi (C6). ${ }^{5}$

Hasil belajar dapat dikelompokkan ke dalam dua macam, yaitu pengetahuan dan keterampilan. Hasil belajar kurikulum adalah kemampuan yang diperoleh setelah melalui kegiatan belajar. Belajar dengan metode neurosains merupakan proses untuk memperoleh perubahan perilaku dari negatif ke positif sehingga tercapai tujuan pembelajaran. Berdasarkan pendapat di

${ }^{4}$ Pendekatan pendidikan dalam pembentukan karakter sangat penting sekali untuk dididik secara tepat supaya menjadi manusia yang berkualitas. Lihat falsafah Undang-undang No. 20 tahun 2003.

${ }^{5}$ Soegeng Santoso sebagaimana dikutip dalam Nurtiani, "Peningkatan Hasil Belajar Pendidikan Agama Islam Dengan Menggunakan Metode Peta Pikiran Bagi Anak Usia Dini (Penelitian Tindakan di kelas I A SD Amaliah CiawiBogor), Jurnal Quantum, Volume 4 No 2 (Juli - Desember 2013). h. 39 
atas, maka hasil belajar melihat kemampuan peserta didik pada aspek pengetahuan, keterampilan, sikap dan nilai yang diwujudkan dalam kebiasaan sehari-hari. ${ }^{6}$

Proses pembelajaran pembentukan karakter di integrasikan dengan berbagai model pelajaran yang memiliki karakteristik, yaitu knowledge dan value. Hal ini mengandung makna bahwa pendidikan neurosains dalam Islam merupakan pelajaran yang memberikan modal pengetahuan Islam sehingga dapat membentuk karakter peserta didik. ${ }^{7}$

Perlunya pendidikan Islam bagi peserta didik diberikan dengan penekanan pada kegiatan yang sesuai kebutuhan kelayakan belajar sebagai alat utama pertumbuhan karakter. Perkembangan berpikir terjadi melalui tiga tahap, pertama, tahap konkrit, peserta didik belajar melalui pengalaman nyata terhadap berbagai objek. Kedua, tahap badaniah, peserta didik belajar melalui sentuhan dan mengamati. Ketiga, tahap abstrak, lebih pada proses berpikir tanpa ada objek. ${ }^{8}$

Apabila peserta didik masuk pada perkembangan konkrit, maka semakin mampu berpikir logis meskipun pelajaran yang bersifat formal belum menjadi akrab. Berdasarkan, hasil penelitian di bidang neurologi, bahwa pertumbuhan sel jaringan otak pada anak usia 0-4 tahun mencapai $50 \%$, hingga usia 8 tahun mencapai $80 \%$ dan kematangan pada 10 - 25 tahun. ${ }^{9}$ Artinya apabila pada urutan usia tersebut otak tidak mendapatkan rangsangan yang optimal maka perkembangannya tidak akan maksimal. Semakin dini penanganan dan bentuk rangsangan yang

${ }^{6}$ Hasil belajar merupakan keluaran (outputs) dari suatu sistem proses masukan (inputs). Masukan dari sistem tersebut bermacam-macam informasi sedangkan keluarannya adalah perbuatan atau kinerja (performance). Lihat Ibid,. h. 43 1970), h. 76

${ }^{7}$ Paulo Freire, Pedagogy of the Oppressed (New York: Seabury Press.,

${ }^{8}$ Hamruni, Edutainment dalam Pendidikan Islam dan Teori-Teori Pembelajaran Quantum (Yogyakarta: UIN Sunan Kalijaga, 2009), h. 38-40

${ }^{9}$ Hamruni, Strategi dan Model-Model Pembelajaran Aktif Menyenangkan (Yogyakarta: UIN Sunan Kalijaga, 2009), h. 61 
diberikan terhadap anak maka hasilnya akan semakin baik. Sebaliknya, semakin lama (lambat), maka semakin buruk hasilnya.

Dalam berbagai materi lain, bahwa kurikulum pembelajaran neurosains juga berkembang disiplin ilmu sistem saraf yang berhubungan antara manusia dengan Tuhan yang sangat berkaitan dengan jasmaniah. Materi spiritualitas dalam pembelajaran neurosains terdiri dari dua variabel yaitu spiritualitas dan intelektualitas. Konsep teoritis spiritualitas terdiri dari tiga komponen yaitu Spiritual Health Item, Brain System Assessment, dan neurofeedback. ${ }^{10}$

Oleh sebab itu, spiritual dalam Islam lebih bersifat individualistik fokus pada pemikiran dan argumentasi yang dianggap benar. Rusdianto mengatakan bahwa hal yang yang harus di hindari oleh lembaga pendidikan adalah pendidikan tanpa karakter seperti Negara tanpa pemimpin. ${ }^{11}$ Begitu pula, Martin Luther King yang pernah berkata kecerdasan plus karakter, itu adalah tujuan akhir dari pendidikan sebenarnya. ${ }^{12}$ Juga Munir Mulkhan yang mengatakan mendidik seseorang dalam aspek kecerdasan otak dan bukan aspek moral adalah ancaman mara bahaya kepada masyarakat. ${ }^{13}$ Bahkan pendidikan yang

${ }^{10}$ Spiritualitas dibedakan dengan agama, dimana agama berarti menganut satu agama dan juga berarti kita masuk dalam suatu komunitas. Indonesia menggunakan alat ukur yang disebut Indonesia Spiritual Health Assessment (ISHA) yang merupakan uji yang dibuat oleh tim Centre for Neuroscience, Health and Spirituality (CNET). Lihat, Rezky A. Yastab, Taufiq Pasiak, Sunny Wangko, "Hubungan Kinerja Otak Dan Spiritualitas Manusia Diukur Dengan Menggunakan Indonesia Spiritual Health Assessment Pada Pemuka Agama di Kabupaten Halmahera Tengah" dalam Jurnal e-Biomedik (eBM), Volume 2, Nomor 2, (Juli 2014)

${ }^{11}$ Rusdianto, Poskolonial Pancasila Indonesia Melawan kanalisasi, (Malang: Bayumedia Publishing, 2013), h. 145

${ }^{12}$ Berkowitz, M., \& Bier, M. dalam Munir Mulkhan, What Works In Character Education, Presentation at the Character Education Partnership National Forum. (Washington, DC. 2003), h. 304

${ }^{13}$ Bohlin, Karen, E. Teaching Character Education through Literature (New York: Routledge Falmer, 2005), h. 211 
menghasilkan manusia berkarakter oleh lembaga pendidikan Islam pondok pesantren telah lama didengung. ${ }^{14}$

Dunia pendidikan saat ini mencoba mengevaluasi sistem pembelajaran untuk menghasilkan manusia berkarakter. Proses pencarian jati diri sistem pendidikan Islam di Indonesia inilah yang merupakan arah untuk mencapai keseimbangan yang positif. Disinilah peran pendidikan Islam sebagai institusi formal dalam menghadapi fenomena degradasi moral. ${ }^{15}$

\section{PEMBENTUKAN KARAKTER PESERTA DIDIK (SANTRI) PONDOK PESANTREN}

Secara etimologis, istilah karakter mengandung arti pembeda yang merujuk pada bentuk khas yang membedakan sesuatu dengan yang lainnya. Selain itu, karakter dapat juga menunjukkan kualitas diri seseorang dengan orang lain. ${ }^{16}$ Dalam pendidikan Islam, istilah karakter digunakan untuk dimensi akhlak dan takwa. ${ }^{17}$ Karakter mempunyai domain moral yang merujuk pada hubungan interpersonal dengan orang lain, misal kasih sayang, empati, loyal, membantu dan peduli dengan orang lain. Sedangkan karakter berdomain nonmoral adalah perilaku yang merujuk pada intrapersonal, seperti bertindak diluar norma nilai maupun aturan. Baik karakter berdomain moral maupun nonmoral tersebut mempunyai tujuan yang sama, yaitu membentuk kepribadian yang peka terhadap kepentingan sosial (prososial). ${ }^{18}$

\footnotetext{
${ }^{14}$ Restianti, H. Peningkatan Mutu Pendidikan dalam Mengajarkan Bahasa Indonesia (Bandung: CV Citra Praya, 2009). h. 34

${ }^{15}$ Budimansyah, D. dkk, Pakem Pembelajaran aktif, kreatif, efektif, dan menyenangkan (Bandung : PT Genesindo, 2010), h. 73

${ }^{16}$ Timpe, Internet Encyclopedia of Philosophy, dari http://www.iep. utm.edu/moral-ch/\#H3). Diakses pada tanggal 21 Maret 2015

${ }^{17}$ Arum Handayani, Penerapan Model Pembelajaran Aktivitas Berpikir dalam Membaca Langsung (Ab-MI) Berbasis Nilai Spiritual dalam Kemampuan Membaca Pemahaman (Jakarta; Universitas Pendidikan Indonesia, 2014), h. 5

${ }^{18}$ DePorter, Bobbi dan Mike Hernacki, Quantum Learning: Membiasakan Belajar Nyaman dan Menyenangkan, terj. Alwiyah Abdurrahman (Cet. 4; Bandung: Kaifa, 1999), h. 97
} 
Sementara, neurosains mengandung kecerdasan emosional untuk menggambarkan kemampuan memahami perasaan dan mengendalikan perasaan secara mendalam sehingga membantu perkembangan emosi dan intelektual. ${ }^{19}$ Ilmuwan Islam juga, Ibnu Rusd menyatakan karakter dalam Islam menjadi alat konstruksi sosial untuk memperbaiki tatanan masyarakat yang dipengaruhi oleh lingkungan sosialnya.

Peterson dan Seligman mengklasifikasikan kekuatan karakter menjadi 6 kelompok, yaitu kognitif, emosional, interpersonal, hidup bersama, menghadapi dan mengatasi hal-hal yang tak menyenangkan dan spiritual. ${ }^{20}$ Megawangi menamakannya "9 Pilar Karakter", yakni cinta Tuhan dan kebenaran; bertanggung jawab, kedisiplinan, dan mandiri; mempunyai amanah; bersikap hormat dan santun; mempunyai rasa kasih sayang, kepedulian, dan mampu kerja sama; percaya diri, kreatif, dan pantang menyerah; mempunyai rasa keadilan dan sikap kepemimpinan; baik dan rendah hati; mempunyai toleransi dan cinta damai. ${ }^{21}$

Pembentukan juga berkaitan dengan pemahaman moral sendiri menurut Damon adalah aturan dalam berperilaku. Aturan tersebut berasal dari kesepakatan atau konsesus sosial yang bersifat universal. Moral yang bermuatan aturan universal tersebut bertujuan untuk pengembangan kepribadian yang positif dan hubungan harmonis. ${ }^{22}$ Pendidikan Islam dalam proses pembentukan moral adalah penentu pembentukan karakter. Oleh karena itu, indikator pembentukan karakter peserta didik (santri)

\footnotetext{
${ }^{19}$ Steven J. Stein \& Book, Howard E, Ledakan EQ; 15 Prinsip Dasar Kecerdasan Emosional Meraih Sukses, terj. Trinanda Rainy Januarsari dan Yudhi Murtanto (Cet. 5; Bandung: Kaifa, 2004), h. 81.

${ }^{20}$ Peterson, Christopher \& Seligman, Martin E. P. Character Strengths and Virtues: A Handbook and Classification (New York: Oxford University Press. 2004), h. 33

${ }^{21}$ Megawangi, dalam http://ihfkarakter.multiply.com/journal, diakses pada tanggal 21 Maret 2015.

${ }^{22}$ William Damon, Moral Child: Nurturing Children's Natural Moral Growth (New York: Free Press. 1988), h. 92
} 
di pondok pesantren dalam suplemen pembelajaran adalah sebagai berikut: ${ }^{23}$

- Education Personal Improvement; yaitu individu yang mempunyai kepribadian yang teguh terhadap aturan yang di internalisasi dalam dirinya. Dengan demikian, tidak mudah goyah dengan pengaruh lingkungan sosial yang dianggap tidak sesuai aturan yang di internalisasi tersebut, sebagaimana penjelasan dan kaidah keimanan. Ciri kepribadian tersebut sebagai integritas muslim yang tinggi terhadap nilai yang di junjung dan tidak melakukan tindakan amoral.

- Education Social Skill; yaitu mempunyai kepekaan sosial yang tinggi sehingga mampu mengutamakan kepentingan orang lain. Hal ini ditunjukkan dengan hubungan sosialnya yang harmonis. Setiap nilai universal akan mengarahkan manusia untuk menjaga hubungan baik dengan orang lain.

- Education Comprehensive Problem Solving; yaitu sejauhmana individu dapat mengatasi konflik dilematis antara pengaruh lingkungan sosial yang tidak sesuai dengan nilai atau aturan dengan integritas pribadinya terhadap nilai tersebut. Dalam arti, individu mempunyai pemahaman terhadap tindakan orang lain yang menyimpang tetapi individu tersebut tetap mendasarkan keputusan dan tindakannya kepada nilai atau aturan yang telah diinternalisasikan dalam dirinya.

\section{PERANGKAT KOLABORATIF PEMBELAJARAN NEUROSAINS}

Hasil-hasil kolaboratif pengajaran antara neurosains dengan pengetahuan umum di berbagai bidang studi terbukti selalu kurang memuaskan berbagai pihak, baik bagi pendidik, sekolah, maupun masyarakat (stakeholder). Hal tersebut setidak-tidaknya disebabkan oleh tiga hal. Pertama, perkembangan kebutuhan dan aktivitas berbagai bidang kehidupan selalu meninggalkan proses dan hasil kerja lembaga pendidikan atau melaju lebih cepat daripada proses pengajaran dan pembelajaran, sehingga hasil-

${ }^{23}$ Nucci, L.P., \& Narvaez, D, Handbook of Moral and Character Education (New York: Routledge, 2008), h. 192 
hasil pengajaran dan pembelajaran tidak relevan dengan kenyataan kehidupan yang diarungi oleh peserta didik. Kedua, pandangan dan temuan dari berbagai bidang tentang pembelajaran dan pengajaran membuat paradigma, falsafah, strategi dan metodologi pembelajaran yang ada sekarang tidak memadai. Ketiga, berbagai permasalahan dan kenyataan negatif tentang hasil pengajaran dan pembelajaran menuntut diupayakannya pembaharuan paradigma, falsafah, strategi dan metodologi pengajaran dan pembelajaran. Dengan demikian, diharapkan mutu dan hasil pembelajaran dapat makin baik dan meningkat. ${ }^{24}$

Oleh karena itu, metodologi pembelajaran silih berganti dipertimbangkan, digunakan atau diterapkan dalam proses pembelajaran dan pengajaran. Metodologi pembelajaran sangat cepat berubah dan berganti, bahkan bermunculan secara serempak, cepat dirasakan usang dan ditinggalkan, kemudian diganti dengan yang lain, malahan sering diumumkan atau dipopulerkan secara serentak beberapa falsafah dan metodologi pembelajaran. ${ }^{25}$

Konsep pembelajaran baru mutakhir menegaskan bahwa setiap orang memiliki potensi otak yang relatif sama, tinggal bagaimana dia mengolahnya. Bila seseorang mampu mengenali tipe belajarnya dan melakukan pembelajaran yang relevan dengan gaya belajar tersebut, maka belajar akan menjadi menyenangkan dan akan memberikan hasil yang optimal. ${ }^{26}$

\footnotetext{
${ }^{24}$ Lihat Hamruni, Edutainment..., h. 99

${ }^{25}$ Beberapa di antaranya yang banyak didiskusikan dan diujicobakan oleh berbagai kalangan, yaitu pembelajaran konstruktivis, pembelajaran kooperatif, pembelajaran terpadu, pembelajaran kontekstual, pembelajaran berbasis projek, pembelajaran berbasis masalah, pembelajaran interaksi dinamis, pembelajaran kuantum, dan pembelajaran aktif (active learning). Lihat Amin Abdullah, Pendidikan Karakter : Mengasah Kepekaan Hati Nurani (makalah) disampaikan pada acara Sarasehan Nasional Pendidikan Karakter (Yogyakarta; Direktorat Jenderal Pendidikan Tinggi Kementerian Pendidikan Nasional Hotel Santika, 2010), h. 2.

${ }^{26}$ Agus Nggermanto, Quantum Qoutient ..., h. 4.
} 
Pendidikan Islam memang lahir dari perangkat neurosains yang dimiliki manusia sehingga sangat penting dalam mengetahui pembelajaran neurosains. Pendidikan Islam mempunyai basis epistimologi pengembangan keilmuan yang wajib - sunnah, fardhu ain / kifayah, dunia-akhirat, dan seterusnya. Menurut Abdul Munir Mulkhan, pendidikan Islam adalah praktik dan derivasi dari seluruh keilmuan. ${ }^{27}$ Dengan asas praktik dan derivasi keilmuan, maka asas tujuan pendidikan Islam mencetak insan kamil yang memiliki jasmani, ruhani dan akal. ${ }^{28}$ Istilah lain yang merujuk pada insan kamil adalah Aql, Nafs, Qolb, Ruh. ${ }^{29}$ Dalam pembelajaran neurosains, istilah tersebut adalah IQ/EQ/SQ. Dalam pendidikan Islam terdapat antara IQ/EQ/SQ, jasmani, ruhani, akal maupun kognitif,

Dalam dunia pendidikan Islam seperti pondok pesantren, paradigma proses pembelajaran bersumber pada peserta didik dan kebijaksanaan dari guru. ${ }^{31}$ Dalam implementasi pembelajaran

\footnotetext{
${ }^{27}$ Abdul Munir Mulkhan, “Kecerdasan Ma'rifat (Ma'rifat Quotient/MaQ), Jalan Pembebasan Manusia dari Mekanisme Konflik" dalam Begawan Muhammadiyah, Bunga Rampai Pidato pengukuhan Guru Besar Tokoh Muhammadiyah (Jakarta: PSAP, 2005), h. 109.

${ }^{28}$ Q.S. Al-Qașaș (28): 77; Q.S. Șād (38): 72

${ }^{29}$ Suyadi, Menerapkan Pendidikan Karakter di Sekolah, (Yogyakarta: Mentari Pustaka, 2012), h. 202

${ }^{30}$ Abdul Munir Mulkhan, dalam Imam Suyadi, Integrasi Pendidikan..., h. 21.

${ }^{31}$ Sebagian ahli lebih suka menganggapnya sebagai asumsi, bukan teori. Pola atau model lain adalah "mengisi botol kosong dengan air pengetahuan". Dalam pola ini, peserta didik adalah penerima pengetahuan yang pasif, dan guru adalah pemilik pengetahuan yang nantinya akan dihafal oleh peserta didik. Ada pula model pembelajaran yang "mengkotak-kotakkan peserta didik". Guru mengelompokkan peserta didik berdasarkan nilai dan memasukkan peserta didik dalam kategori, siapa yang berhak naik kelas, siapa yang tidak, siapa yang bisa lulus dan siapa yang tidak. Kemampuan dinilai dengan ranking dan peserta didik pun direduksi menjadi angka-angka. Dalam pola ini, peserta didik dipacu dalam kompetisi yang tidak sehat, bagaikan "ayam aduan". Peserta didik bekerja keras untuk mengalahkan teman sekelasnya. Siapa yang kuat, dia yang menang. Orang tua pun saling bersaing memuji anaknya masingmasing dan menonjolkan prestasi mereka Lihat, Anita Lie, Cooperative Learning: Mempraktikkan Cooperative Learning di Ruang-Ruang Kelas (Cet. 3; Jakarta: Grasindo, 2004), h. 2
} 
neurosains dalam dunia pendidikan sudah banyak berubah. Karena jarang tersentuh teori, penelitian dan pelaksanaan belajar mengajar membuktikan bahwa para guru sudah harus mengubah paradigma pengajaran neurosains. Maka, tiga model pembelajaran neurosains dapat di implementasikan dalam pendidikan pondok pesantren, yaitu model kompetisi, individual, dan kerjasama dengan keunggulan dan kelemahan masingmasing peserta didik yang diarahkan pada proses individu dan interaksi lingkungan sosial.

Menurut Silberman, bahwa belajar aktif melakukan kegiatan peserta didik, seperti gagasan, memecahkan masalah dan praktek. $^{32}$ Model pembelajaran aktif adalah proses membuka dan memberi kesempatan seluas-luasnya pada peserta didik untuk terlibat, baik dengan cara mendengar, melihat, bertanya maupun berdiskusi dengan peserta didik lainnya. Mereka didorong untuk belajar memecahkan masalah secara terampil dan melakukan tugas sesuai yang mereka miliki dengan kondisi pembelajaran penuh gairah, menyenangkan, dan menarik.

Penelitian lain mengungkapkan bahwa kemampuan peserta didik mendengarkan (tanpa berfikir) rata-rata 400-500 kata perhari. Ketika aktivitas mendengar dilakukan secara terus menerus selama waktu tertentu dengan mengikuti guru berbicara maka peserta didik cenderung merasa bosan dan jenuh. Padahal dalam pengajaran bergaya ceramah, perhatian peserta didik hanya bertahan sekitar $40 \%$ dari seluruh waktu belajar.

Cara paling baik adalah yang penting dapat mengingat materi yang diterima, tetapi dalam mata pelajaran terakhir peserta didik hanya dapat mengingat sekitar 20\% materi pembelajaran tersebut. ${ }^{33}$ Kemampuan mengingat ini bisa ditingkatkan 50 persen bila pembelajaran menggunakan media visual. Peningkatan akan mencapai 200 persen bila kosa kata juga

\footnotetext{
${ }^{32}$ Mel Silberman, Active Learning: 101 Strategies to Teach Any Subject (Massachusetts, 1996), h. 17.

${ }^{33}$ McKeachie, W, Teaching Tips: A Guidebook for the Beginning College Teacher (Boston: D.C. Health, 1986), h. 63.
} 
diajarkan di samping penggunaan media audio visual. ${ }^{34}$ Maka perkembangan neurosains di kolaborasikan dengan metodologi pembelajaran yang menggunakan pendekatan SAVI (Somatis belajar dengan bergerak dan berbuat, Auditori belajar dengan berbicara dan mendengar, Visual belajar dengan mengamati dan menggambarkan, dan Intelektual belajar dengan memecahkan masalah dan merenung). ${ }^{35}$

Pendekatan ini didasarkan pada sebuah konsep belajar yang disebut Belajar Berdasar Aktivitas (BBA) yang bergerak aktif secara fisik ketika belajar dengan memanfaatkan indra tubuh dan pikiran terlibat dalam poses belajar berdasarkan aktivitas lapangan secara efektif daripada presentasi, materi, dan media. Alasannya sederhana cara belajar itu mengajak orang terlibat sepenuhnya. Telah terbukti berkali-kali bahwa biasanya orang belajar lebih banyak dari berbagai aktivitas dan pengalaman yang dipilih daripada belajar dikelas dengan buku panduan, televisi, ataupun komputer. ${ }^{36}$ Memang, pembelajaran tidak otomatis meningkat dan dapat menggabungkan fisik dengan aktivitas intelektual maupun penggunaan semua indra yang berfungsi sebagai perekam pembelajaran.

Para pendidik hendaknya memahami dan menyesuaikan diri dengan paradigma pembelajaran neuronsains yang berkembang saat ini. Paradigma pembelajaran ini menghendaki adanya pemahaman bahwa peserta didik dapat menemukan dan mengembangkan pengetahuannya. Guru juga harus menciptakan kondisi dan situasi yang memungkinkan peserta didik membentuk pelajaran melalui suatu proses belajar yang dan mudah mengingatnya. ${ }^{37}$ Dalam pembelajaran, peserta didik harus

\footnotetext{
${ }^{34}$ Pike, R., Creative Training Techniques Handbook (Minneapolis, MN: Lakewood Books, 1989), h. 132.

${ }^{35}$ Dave Meir, The Accelerated Learning Handbook (New York: McGraw Hill, 2000), h. 92

${ }^{36}$ Rickard, et. al., "Some Retention, But Not Enough," In Teaching of Psychology (Portland, OR, Metamorphus Press,1988), h. 151-152.

${ }^{37}$ Jean Piaget, The Origins of Intelligence in Children (New York: International University Press, 1952), h. 153. Lihat juga, Jean Piaget, The Child's
} 
diberi kesempatan untuk membangun pengetahuan secara aktif dalam kegiatan yang dilakukan peserta didik sehingga dapat menerima pengetahuan dari sumber kurikulum yang telah di susun. $^{38}$

Selain itu, guru perlu mengembangkan kompetensi dan kemampuan peserta didik dengan kegiatan belajar mengajar yang lebih lebih menekankan proses karena setiap peserta didik mempunyai potensi yang lebih baik. Paradigma mengembangkan kompetensi dan potensi peserta didik berdasarkan kemampuan peserta didik sendiri. ${ }^{39}$ Dalam lemabaga pendidikan terjadi interaksi antara antara guru dan peserta didik merupakan proses sosial yang terjadi dalam lingkungannya. Karena belajar juga menekankan hubungan sosial kekerabatan antar sesama. ${ }^{40}$

Untuk mencapai pembelajaran yang efektif, suasana kelas perlu direncanakan dan dibangun sedemikian rupa, sehingga peserta didik mendapatkan kesempatan untuk berinteraksi satu sama lain. Oleh karena itu, pendidikan neurosains menciptakan suasana belajar yang kondusif dan nyaman dalam berbagai aktivitas pemebelajaran kurikulum pendidikan Islam, meliputi: ${ }^{41}$

- Kecerdasan Khusus, konsep neurosains dapat dilihat dari tingkat kecerdasan dilihat hanya dari sisi kekuatan verbal dan logika seseorang yang akhirnya dapat dinilai dengan angka konstan dan menganut konsep eugenic artinya pengendalian sistematis dari keturunan. Perkembangannya dengan

Conception of the World (Atlantic Highlands, N.J.: Humanities Press, Inc., 1960), h. 232; Freire, R., Pedagogy..., , h. 147.

${ }^{38}$ T. Anderson, \& Armbruster, B., Reader and Text Studying Strategies,. W. Otto \& S. White (eds.), Reading Expository Material (New York: Academic Press., 1982), h. 215. 1982), h. 78 .

${ }^{39}$ Carl Rogers, Freedom to Learn for the Eighties (Columbus: E. Merrill,

${ }^{40}$ D.W. Johnson \& R. Johnson, Leading the Cooperative School (Edina, MN: Interaction Book Company, 1994), h. 112.

${ }^{41}$ Primatia Yogi Wulandari, Karakter Anak = Karakter TV, Peran Media Massa dalam Pembentukan Karakter Anak. Makalah untuk Himpunan Psikologi Indonesia (HIMPSI) Wilayah Jawa Timur (Surabaya: Fakultas Psikologi Universitas Airlangga, 2010), h. 2. 
merancang tes IQ yang diperbaharui dengan nama Scholastic Aptitute Test(SAT).

- Kecerdasan umum (general intelegence), konsep manusia mempunyai kemampuan mental umum ( $G$ ) yang mendasari semua kemampuannya untuk menangani kesulitan kognitif. Faktor $G$ ini meliputi kemampuan memecahkan masalah, pemikiran abstrak, dan keahlian dalam pembelajaran.

- Kecerdasan Cair dan Kecerdasan Cristal (Fluid and Crystaled Intelligence), konsep manusia mempunyai 2 macam kecerdasan umum, yaitu kecerdasan cair dan kecerdasan kristal. Kecerdasan ini dapat terus meningkat tidak ada batas maksimal selama manusia mau dan bisa belajar.

- Kecerdasan yang dapat dimodifikasi (Modifiable Intelligence), konsep kecerdasan dapat diukur dari kemampuan berpikir seseorang yang mana kemampuan berpikir manusia tersebut mempunyai tahap-tahap perkembangan.

- Kecerdasan Proksimal (Proximal Intelligence), konsep kecerdasan kognitif seseorang dapat diuji dengan memperhatikan kronologis usia mental orang tersebut dan memperhatikan kapasitas orang tersebut. Maksud kapasitas seseorang adalah perbandingan kemampuan seseorang menyelesaikan suatu masalah seseorang diri dengan apabila mendapat bantuan orang lain dalam menyelesaikan masalah yang serupa.

- Kecerdasan yang dapat dipelajari (Learnable Intelligence), konsep kecerdasan dipengaruhi dan dioperasikan oleh beberapa faktor dalam kehidupan yaitu sistem orak, pengalaman hidup, dan kapasitas untuk pengaturan diri.

- Kecerdasan Prilaku (Behaviour Intelligence), bahwa konsep kecerdasan diartikan sebagai suatu kumpulan dari kecenderungan perilaku. Perilaku tersebut antara lain keuletan, kemampuan mengatur perilaku impulsif, empati, fleksibilitas berpikir, metakognisi, akurasi, kemampuan 
bertanya, bahasa, kepekaan panca indera, kebijaksaan, rasa ingin tahu, dan kemampuan mengalihkan perasaan.

- Kecerdasan Tritunggal (Triarchic Intelligence), konsep kecerdasan manusia dapat diukur dari keseimbangan tiga kecerdasan yaitu kecerdasan kreatif, analisis, dan praktis. Kecerdasan kreatif meliputi kemampuan menemukan dan merumuskan ide serta solusi dari masalah.

- Kecerdasan Moral (Moral Intelligence), bahwa konsep Kecerdasan yang menitikberatkan pada prinsip dan nilai-nilai hidup.

- Kecerdasan Emosional (Emotional Intelligence), konsep kecerdasan dapat terdiri dari kombinasi 5 komponen, yaitu kesadaran diri, manajemen emosi, motivasi, empati, dan mengatur hubungan / relasi.

- Kecerdasan Memecahkan Kesulitan (Adversity Intelligence), konsep kecerdasan seseorang dapat diukur dari kemampuan orang tersebut mengatasi masalah yang dialami dalam hidup. Kecerdasan seseorang dapat diklasifikasikan menjadi berbagai ciri dan sifat yaitu Quitter, Camper, dan Climber.

- Kecerdasan Majemuk (Multiple Intelligence), konsep setiap orang mempunyai lebih dari satu kecerdasan, minimal memiliki delapan kecerdasan yaitu linguistik, logikamatematika, intrapersonal, musikal, naturalis, visual-spasial, dan kinestestis. Setiap orang memiliki delapan kecerdasan ini dengan kadar perkembangan yang berbeda-beda.

\section{IMPLEMENTASI KARAKTER NEUROSAINS DI ERA GLOBAL}

Begitu pula halnya dengan perkembangan karakter yang bersifat bawaan lahir dapat dibentuk melalui didikan lingkungan. Satu hal yang jelas bahwa interaksi antara aspek nature dan nurture dalam perkembangan karakter individu, yang dibuktikan dengan penelitian-penelitian para ahli. ${ }^{42}$ Faktor determinan

${ }^{42}$ Y. Abidin, Pembelajaran Bahasa Berbasis Pendidikan Karakter. (Bandung: PT Refika Aditama, 2012). h. 87 
karakter berupa biologis untuk mengungkap pengaruh yang biasanya dilakukan pada peserta didik serta bersifat longitudinal yang memiliki pengaruh genetis yang cukup kuat terhadap karakter peserta didik. ${ }^{43}$ Beberapa dimensi karakter seperti empati dan simpati juga banyak diamati melalui perspektif neurosains yang lebih mengarah kepada herediter. ${ }^{44}$

Di sisi lain, lingkungan keluarga membawa pengaruh yang cukup penting bagi pembentukan karakter peserta didik. Kochanska, dkk. menyatakan kelekatan antara orangtua dan peserta didik penting bagi perkembangan karakter dengan ${ }^{45}$ secara menyeluruh, meliputi relasi orangtua dan peserta didik melalui dukungan, serta pemahaman akan membawa dampak terhadap karakter peserta didik. ${ }^{46}$

Sekolah, sebagai lingkungan kedua, turut mempengaruhi konsep diri, keterampilan sosial, nilai, kematangan penalaran moral, perilaku prososial, pengetahuan tentang moralitas, dan sebagainya. ${ }^{47}$ Adanya ikatan yang kuat dengan sekolah termasuk juga kedekatan dengan guru, merupakan dasar bagi perkembangan prososial dan karakter peserta didik sehingga menerapkan sebuah standar ikatan emosi, komitmen, dan

${ }^{43}$ J. Dunn, \& C. Hughes, I Got Some Swords And You're Dead: Violent Fantasy, Antisocial Behavior, Friendship And Moral Sensibility In Young Children. Child Development (Cet. 7; t.tp.: tp., 2001), h. 491.

${ }^{44}$ A. Caspi, K. Sugden, T. E. Moffitt, A. Taylor, I. W. Craig A., H. Harrington, et al. Influence of life stress on depression: Moderation by a polymorphism in the 5-HTT gene (American: Science, 2003), h. 386

${ }^{45} \mathrm{G}$. Kochanska, N. Aksan, \& K. E. Nichols, Maternal Power Assertion In Discipline And Moral Discourse Contexts: Commonalities, Differences, And Implications For Children's Moral Conduct And Cognition. (Developmental Psychology, 2003), h. 949.

${ }^{46}$ J. E. Grusec, J. J. Goodnow, \& L. Kuczynski, New directions in analyses of parenting contributions to children's acquisition of values. (Child Development, 2000), h. 211.

${ }^{47} \mathrm{M}$. L. Mares \& E H. Woodard, Positive Effects of Television On Children's Social Interactions: A Meta Analysis (Media Psychology, 2005), h. 322. 
kedekatan dengan sekolah. ${ }^{48}$ Dalam hal ini, sekolah perlu memiliki atmosfir moral dalam rangka meningkatkan tanggung jawab dan mengurangi pelanggaran di sekolah ${ }^{49}$ Di lingkungan sekolah, tentu saja anak mengalami perluasan aktivitas. Relasi dengan teman sebaya pun akan membawa dampak terhadap pembentukan karakter peserta didik. Hubungan emosi yang kuat dan aktivitas bermain merupakan mediator bagi anak untuk mengembangkan karakter. ${ }^{50}$

Tidak kalah penting pengaruh lingkungan terhadap karakter peserta didik melalui televisi dan media permainan elektronik lainnya. ${ }^{51}$ Hal ini menunjukkan bahwa lingkungan sosial mempunyai andil dalam pembentukan moral dan karakter peserta didik. Pembentukan karakter moral dipengaruhi oleh interaksi yang bersifat herediter dengan faktor lingkungan, pertama, peranan sekolah dalam pembangunan manusia berkarakter moral. ${ }^{52}$ Kedua, menyediakan pendidikan moral agama yang berbasis penyikapan terhadap fenomena. Ketiga, menyiapkan guru, kakak kelas, civitas akademika, alumni sebagai role model. Keempat, membangun sinergitas antara pihak sekolah, keluarga, masyarakat dan pemerintah. Kelima, pendidikan berkarakter moral dimasukkan dalam kegiatan intra, ekstra dan ko-kulikuler sebagai hidden curriculum. Keenam, menyajikan story telling melalui multi media dengan melibatkan peran sebagai role model karakter moral..$^{53}$

\footnotetext{
${ }^{48}$ Hawkins, dkk. dalam Suharsimi Arikunto, Prosedur Penelitian: Suatu pendekatan praktik (Edisi Revisi Jakarta: PT Rineka Cipta, 2001), h. 377.

${ }^{49}$ S. Aman, Trend Spiritual Milenium Ketiga (Banten: Ruhama, 2013), h. 43.

${ }^{50}$ I. Cahyati, Menulis Proposal Penelitian (Edisi 1; Bandung: CV Bintang Warli Artika, 2011), h. 221

${ }^{51}$ Lee Sheldon, Character Development and Story Telling (Boston: Thomson. 2004), h. 105.

${ }^{52}$ I. Silberman, Religion as a meaning system: implications for the new millennium (Journal of Social Issues Vol. 2 No. 4, 2005), h. 663.

${ }^{53}$ J. Decety \& T. Chaminade, Neural correlates of feeling sympathy (Neuropsychologia, 2003), h. 138.
} 
Daniel Goleman mengatakan ${ }^{54}$ kecerdasan emosional sebagai kemampuan untuk memotivasi diri sendiri dan bertahan menghadapi frustasi; mengendalikan dorongan hati dan tidak melebih-lebihkan kesenangan; mengatur suasana hati dan menjaga agar beban stres tidak melumpuhkan kemampuan berpikir; berempati dan berdoa. Dengan demikian, story telling memiliki kemampuan untuk menyampaikan nilai-nilai moral karena anak dan remaja lebih mudah menerima informasi melalui audio visual. Oleh karena itu, disarankan story telling disajikan dalam multi media sehingga menarik keterlibatan afeksi dan kognisi peserta didik dalam menginternalisasi nilai moral yang disampaikan.

Dalam Islam sebagaimana Alquran menjelaskan bahwa aktifitas kecerdasan emosional seringkali dihubungkan dengan qalb (kalbu). Oleh karena itu, kata kunci utama $E Q$ di dalam Alquran dapat ditelusuri melalui kata kunci qalb (kalbu) dan tentu saja dengan istilah-istilah lain yang mirip dengan fungsi kalbu seperti jiwa (nafs), intuisi (hadas), dan beberapa istilah lainnya. ${ }^{55}$ Lebih lanjut, jenis-jenis dan sifat kalbu (qalb) dalam Alquran ada dua kelompok, yaitu ${ }^{56}$ pertama kalbu yang positif seperti kalbu yang damai (qalb salim), ${ }^{57}$ kalbu yang bertaubat (qalb munib), ${ }^{58}$ kalbu yang tenang (qalb muthmainah), ${ }^{59}$ kalbu yang berfikir (qulub ya'qilun), ${ }^{60}$ kalbu yang mukmin (qulub al mu'min). ${ }^{61}$ dan kedua, kalbu yang negatif, terdiri dari kalbu yang sewenangwenang (qalb mutakabbir), ${ }^{62}$ kalbu yang sakit (qalb maridh), ${ }^{63}$

\footnotetext{
${ }^{54}$ Daniel Goleman, Kecerdasan Emosional, terj. T. Hermaya (Cet. 13; Jakarta: Gramedia Pustaka Utama, 2003), h. 376.

${ }^{55}$ M. Darwis Hude, Emosi; Penjelajahan Religio-Psikologis tentang Emosi Manusia di dalam Al Qur'an (Jakarta: Erlangga, 2006), h. 74.

${ }^{56}$ Ibid., h. 77.

${ }^{57}$ Q.S. al-Syu'arā' (26): 89

${ }^{58}$ Q.S. Qaaf (50): 33

${ }^{59}$ Q.S. al-Nahl (16): 6

${ }^{60}$ Q.S. al-Hajj (22): 46

${ }^{61}$ Q.S. al Fath (48): 4

${ }^{62}$ Q.S. al Mu'min (40): 35
} 
kalbu yang melampaui batas (qulub al mu'tadin), ${ }^{64}$ kalbu yang berdosa (qulub mujrimin) ${ }^{65}$ Kalbu yang terkunci, tertutup (khatama Allah 'ala qulubihim), ${ }^{66}$ dan kalbu yang terpecah-pecah (qulubuhum syatta). ${ }^{67}$

Agustian membagi emosi ke dalam kategori emosi yang tercipta ketika manusia menjauh atau keluar dari garis orbit (off line) dan emosi yang masuk dalam garis orbit (in line). Yang masuk dalam kategori off line adalah emosi yang keluar dari tuntutan hati nurani, sedangkan in line adalah yang sesuai dengan hati nurani. Emosi-emosi tersebut antara lain $^{68}$ marah, ketika harga diri terguncang (off line), kecewa, ketika suara hati tidak sesuai dengan kenyataan (off line), sedih, pada saat merasa kehilangan (off line), menangis, ketika God Spot tergetar (off line atau in line), bahagia, ketika suara hati tersentuh (in line), merasa damai, ketika suara hati menjadi kenyataan (in line), termotivasi, ketika bersemangat untuk merealisasikan suara hati (in line), antusias, saat diri merasa mampu untuk merealisasikan suara hati (off line), merasa aman, ketika suara hati terpenuhi (in line), kesal, ketika sebuah kenyataan jauh dari suara hati (off line), dan menyesal, ketika kesempatan untuk mengaplikasikan suara hati terlewatkan (off line).

Adapun pembagian emosi menurut Daniel Goleman adalah ${ }^{69}$ amarah; seperti beringas, mengamuk, benci, marah besar, jengkel, kesal hati, terganggu, rasa pahit, berang, tersinggung, bermusuhan, dan tindak kekerasan; kesedihan; seperti pedih, sedih, muram, suram, melankolis, mengasihani diri, kesepian,

\footnotetext{
${ }^{63}$ Q.S. al Ahzab (33): 32

${ }^{64}$ Q.S. Yunus (10): 74

${ }^{65}$ Q.S. al Hijr (15): 12

${ }^{66}$ Q.S. al Baqarah (2): 7

${ }^{67}$ Q.S. al Hasyr (59): 14

${ }^{68}$ Ari Ginanjar Agustian, Rahasia Sukses Membangkitkan ESQ Power; Sebuah Inner Journey melalui al Ihsan (Cet. 10; Jakarta: Arga, 2006), h. 44.

${ }^{69}$ Daniel Goleman dalam R Conny Semiawan, Kreativitas Keberbakatan: Mengapa, Apa, dan Bagaimana (Jakarta: PT Indeks, 2003), h. 412.
} 
ditolak, putus asa, depresi berat; rasa takut; seperti cemas, takut, gugup, khawatir, waspada, tidak tenang, was was, fobia, dan panik; kenikmatan; seperti bahagia, gembira, riang, puas, terhibur, bangga, takjub, senang sekali; cinta; seperti penerimaan, persahabatan, kepercayaan, kebaikan hati, rasa dekat, bakti, hormat, kasmaran, kasih; terkejut; takjub, terkesiap, terpana, jengkel, jijik, muak, mual, benci, tidak suka, mau muntah; dan malu; rasa salah, malu hati, kesal hati, hina, aib, hati hancur lebur.

Uraian tersebut di atas jelas memperlihatkan bahwa qalb (kalbu) secara psikologis memiliki daya-daya emosi yang menimbulkan daya rasa (al syu'ur) yang positif atau yang negatif. Jika daya rasa positif diupayakan untuk selalu diberdayakan, maka potensi ini sangat mungkin untuk dapat dijadikan sebagai media pengembangan tingkah laku salih yang berbasis rasa cinta, senang, riang, percaya (iman), tulus (ikhlas) dan rasa persaudaraan.

Namun jika daya rasa negatif yang dibiarkan, tanpa ada upaya pengendaliannya, maka perilaku yang tampak dipermukaan cenderung selalu menolak terhadap kebenaran, sekalipun datangnya dari Tuhan. Hal ini dapat terjadi, dikarenakan keadaan psikologis sudah didominasi oleh daya rasa kebencian, ketidaksenangan, kekufuran, keingkaran dan kemunafikan, yang dalam bahasa al Ghazali disebut al Ghadlab. ${ }^{70}$ Oleh karena itu, daya-daya emosi tersebut harus dikelola dan diatur sedemikian rupa agar lebih cerdas secara emosional.

Selain itu, terdapat 5 (lima) dimensi $E Q$, adalah mengenali emosi diri (self awareness), mengelola emosi (self regulation), memotivasi diri sendiri (motivation), mengenali emosi orang lain (empathy), dan membina hubungan atau keterampilan sosial (social skill), yakni mengenali emosi diri (self awareness), mengelola emosi (self regulation), memotivasi diri sendiri

${ }^{70}$ Abdullah Hadziq, Rekonsiliasi Psikologi Sufistik dan Humanistik (Semarang: RaSAIL, 2005), h. 320. 
(motivation), menata emosi sebagai alat untuk mencapai tujuan, mengenali emosi orang lain (empathy), dan membina hubungan atau keterampilan sosial (social skills). ${ }^{71}$ Pengetahuan tentang otak tidak saja penting dalam proses pembelajaran (learning), tetapi keseluruhan dalam proses pendidikan. ${ }^{72}$

\section{PENUTUP}

Pembelajaran neurosains dapat digunakan di lembaga pendidikan Islam seperti pondok pesatren. Hal itu bertujuan untuk mengetahui preferensi kecerdasan peserta didik mulai dari sikap, prilaku, kemampuan belajar dan emosionalnya. Pembelajaran neurosains sebagai suplemen kurikulum yang telah ada merupakan metode yang menarik untuk di terapkan. Apalagi ada sistem kolaborasi pembelajaran umum dengan pendidikan agama Islam sebagai basis pengembangan kemampuan belajar peserta didik. Output pembelajaran neuronsains sendiri dapat membentuk karakter peserta didik hingga dewasa sehingga mereka tidak di kenal eksklusif dan dapat menerima lingkungan sosial sekitarnya.

Pembelajaran memakai metode neurosains dengan kolaborasi kurikulum sangat penting bagi pondok pesantren karena selama ini di mana pondok sebagai justifikasi sumber gerakan radikalisme. Maka penting bagi pondok pesantren menggunakan metodologi ini sebagai basis pengembangan ilmu pengetahuan dan metodologi pengembangan kempuan mobilitas sosial peserta didik yang selama ini di inginkan.

${ }^{71}$ Sukidi, Rahasia Sukses Hidup Bahagia Kecerdasan Spiritual; Mengapa SQ Lebih Penting daripada IQ dan EQ (Cet. 2; Jakarta: Gramedia Pustaka Utama, 2004), h. 204.

${ }^{72}$ Muhtar Sadili, Kecerdasan Paripurna Anak Didik" dalam http://groups.google.com. Diakses pada tanggal 22 Maret 2015. 


\section{DAFTAR PUSTAKA}

Abidin, Y. Pembelajaran bahasa berbasis pendidikan karakter, Bandung: PT Refika Aditama, 2012.

Agustian, Ari Ginanjar, Rahasia Sukses Membangkitkan ESQ Power; Sebuah Inner Journey melalui al Ihsan, Cet.10; Jakarta: Arga, 2006.

Aman, S., Trend Spiritual Milenium Ketiga, Banten: Ruhama, 2013.

Anderson, T. \& B. Armbruster, Reader and Text Studying Strategies,. W. Otto \& S. White (eds.), Reading Expository Material, New York: Academic Press, 1982.

Arikunto, Suharsimi, Prosedur Penelitian : Suatu pendekatan praktik, Edisi Revisi Jakarta: PT Rineka Cipta, 2001.

Arum, Handayani, Penerapan Model Pembelajaran Aktivitas Berpikir Dalam Membaca Langsung (Ab-Ml) Berbasis Nilai Spiritual Dalam Kemampuan Membaca Pemahaman, Jakarta: Universitas Pendidikan Indonesia, 2014.

Berkowitz, M., \& Bier, M. What works in character education. Presentation at the Character Education Partnership National Forum. Washington, DC. 2003.

Budimansyah, D. dkk, Pakem Pembelajaran aktif, kreatif, efektif, dan menyenangkan. Bandung : PT. Genesindo, 2010.

Cahyati, I. Menulis Proposal Penelitian. Edisi 1. Bandung: CV Bintang Warli Artika, 2011.

Caspi, A., K. Sugden, T. E. Moffitt, A. Taylor, I. W. Craig, H. Harrington, , et al., The Origins of Intelligence in Children, New York: International University Press, 1952.

Caspi, A., Sugden, K., Moffitt, T. E., Taylor, A., Craig, I. W., Harrington, H., et al. Influence of life stress on depression: Moderation by a polymorphism in the 5-HTT gene. American: Science, 2003. 
Damon, W, Moral child: Nurturing children's natural moral growth. New York: Free Press. 1988.

Decety, J., \& T. Chaminade, Neural correlates of feeling sympathy, Neuropsychologia, 2003.

DePorter, Bobbi dan Mike Hernacki, Quantum Learning: Membiasakan Belajar Nyaman dan Menyenangkan, terj. Alwiyah Abdurrahman, Bandung: Kaifa, Cet. 4, 1999.

Dunn, J., \& Hughes, C. I Got Some Swords And You're Dead: Violent Fantasy, Antisocial Behavior, Friendship And Moral Sensibility In Young Children. Child Development, Cet. 7; t.tp.: t.p., 2001.

Freire, Paulo, Pedagogy of the Oppressed, New York: Seabury Press, 1970.

Gardner, Howard, The School of The Future. In John Brockman (ed), Ways of Knowing: The Reality Club, (Englewood Cliffs, N.J.: Prentice Hall, 2002.

Goleman, Daniel, Kecerdasan Emosional, terj. T. Hermaya, Cet. 13; Jakarta: Gramedia Pustaka Utama, 2003.

Grusec, J. E., Goodnow, J. J., \& Kuczynski, L. New directions in analyses of parenting contributions to children's acquisition of values. Child Development, 2000.

Hadziq, Abdullah, Rekonsiliasi Psikologi Sufistik dan Humanistik, Semarang: Rasail, 2005.

Hamruni, Edutainment Dalam Pendidikan Islam dan Teori-Teori Pembelajaran Quantum, Yogyakarta: Fakultas Tarbiyah UIN Sunan Kalijaga Yogyakarta, 2009.

Hamruni, Strategi dan Model-Model Pembelajaran AktifMenyenangkan, Yogyakarta: Fakultas Tarbiyah UIN Sunan Kalijaga Yogyakarta, 2009. 
Hude, M. Darwis, , Emosi; Penjelajahan Religio-Psikologis tentang Emosi Manusia di dalam Al Qur'an, Jakarta: Erlangga, 2006.

Piaget, Jean, The Child's Conception of the World, Atlantic Highlands, N.J.: Humanities Press, Inc., 1960.

Piaget, Jean, The Origins of Intelligence in Children, New York: International University Press, 1952

Johnson, D.W. \& Johnson, R., Leading the Cooperative School, Edina, MN: Interaction Book Company, 1994.

Kochanska, G., Aksan, N., \& Nichols, K. E. Maternal Power Assertion In Discipline And Moral Discourse Contexts: Commonalities, Differences, And Implications For Children's Moral Conduct And Cognition. Developmental Psychology, 2003.

Lie, Anita, Cooperative Learning: Mempraktikkan Cooperative Learning di Ruang-Ruang Kelas, Cet. 3; Jakarta: Grasindo, , 2004.

Mares, M. L., \& E H. Woodard, Positive Effects Of Television On Children's Social Interactions: A Meta Analysis. Media Psychology, 2005.

McKeachie, W., Teaching Tips: A Guidebook for the Beginning College Teacher, Boston: D.C. Health, 1986.

Megawangi, dalam http://ihfkarakter.multiply.com/journal, Diakses pada tanggal 21 Maret 2015

Meir, Dave, The Accelerated Learning Handbook (New York: McGraw Hill, 2000), h. 92

Mulkhan, Abdul Munir, Kecerdasan Ma'rifat (Ma'rifat Quotient/MaQ), Jalan Pembebasan Manusia dari Mekanisme Konflik, dalam "Begawan Muhammadiyah", Bunga Rampai Pidato pengukuhan Guru Besar Tokoh Muhammadiyah, Jakarta: PSAP, 2005. 
Nggermanto, Agus, Quantum Qoutient (Kecerdasan Quantum): Cara Praktis Melejitkan IQ, EQ, dan SQ Yang Harmonis, Bandung: Nuansa, 2005.

Nucci, L.P., \& Narvaez, D, Handbook of Moral and Character Education. New York: Routledge, 2008.

Nurtiani, Ayi Teiri, "Peningkatan Hasil Belajar Pendidikan Agama Islam Dengan Menggunakan Metode Peta Pikiran Bagi Anak Usia Dini (Penelitian Tindakan di kelas IA SD Amaliah CiawiBogor), dalam Jurnal Quantum, Vol. 4 No. 2 (Juli-Desember 2013), h.39-43.

Peterson, Christopher \& Seligman, Martin E. P. Character Strengths and Virtues: A Handbook and Classification. New York: Oxford University Press. 2004.

Pike, R., Creative Training Techniques Handbook Minneapolis, MN: Lakewood Books Meir, Dave, The Accelerated Learning Handbook, New York: McGraw Hill, 2000.

Restianti, H. Peningkatan mutu pendidikan dalam mengajarkan bahasa Indonesia, Bandung: CV Citra Praya, 2009.

Rezky A. Yastab, Taufiq Pasiak, Sunny Wangko, "Hubungan Kinerja Otak Dan Spiritualitas Manusia Diukur Dengan Menggunakan Indonesia Spiritual Health Assessment Pada Pemuka Agama di Kabupaten Halmahera Tengah" dalam Jurnal e-Biomedik (eBM), Vol. 2, No 2, (Juli 2014), h. 419-424

Rickard, et. al., "Some Retention, But Not Enough," In Teaching of Psychology Portland, OR, Metamorphus Press,1988.

Rogers, Carl, Freedom to Learn for the Eighties, Columbus: E. Merrill, 1982.

Rusdianto, Poskolonial Pancasila Indonesia Melawan kanalisasi, Malang: Bayumedia Publishing, 2013 
Sadili, Muhtar, "Kecerdasan Paripurna Anak Didik" dalam http://groups.google.com. Diakses pada tanggal 22 Maret 2015

Semiawan, R Conny, Kreativitas Keberbakatan: Mengapa, Apa, dan Bagaimana, Jakarta: PT Indeks, 2009.

Sheldon, Lee. Character Development and Story Telling, Boston: Thomson. 2004.

Silberman, I. Religion as a meaning system: Implications for the new millennium. Journal of Social Issues Vol. 2 No. 4, (2005).

Silberman, Mel, Active Learning: 101 Strategies to Teach Any Subject (Massachusetts, 1996), h. 17.

Stein, Steven J. \& Book, Howard E, Ledakan EQ; 15 Prinsip Dasar Kecerdasan Emosional Meraih Sukses, terj. Trinanda Rainy Januarsari dan Yudhi Murtanto, Cet. V, Bandung: Kaifa, 2004.

Sukidi, Rahasia Sukses Hidup Bahagia Kecerdasan Spiritual; Mengapa SQ Lebih Penting daripada IQ dan EQ, Cet. 2; Jakarta: Gramedia Pustaka Utama, 2004.

Suyadi, Imam, Menerapkan Pendidikan Karakter di Sekolah, Yogyakarta: Mentari Pustaka, 2012.

Suyadi, Integrasi Pendidikan Islam dan Neurosains dan Implikasinya Bagi Pendidikan Dasar (PGMI), Yogyakarta: Jurnal Al-Bidāyah, Vol 4 No. 1, (Juni 2011), h. 111-130.

Timpe, Internet Encyclopedia of Philosophy. Diakses 21 April 2010, dari http://www.iep.utm.edu/moral-ch/\#H3). Diakses pada tanggal 21 Maret 2015.

Undang-undang No. 20 tahun 2003

William, Damon (Ed), Bringing in a New Era in Character Education. USA: Hoover Institution Press Publication, 2002. 
Wulandari, Primatia Yogi, Karakter Anak $=$ Karakter TV, Peran Media Massa dalam Pembentukan Karakter Anak. Makalah untuk Himpunan Psikologi Indonesia (HIMPSI) Wilayah Jawa Timur, Surabaya: Fakultas Psikologi Universitas Airlangga, 2010. 